\title{
HIGH SCHOOL SCIENCE STUDENTS' IDEAS ABOUT MICROORGANISMS AND THEIR PLACE IN THE CURRICULUM
}

\author{
Solmaz Aydın 1 \\ ${ }^{1}$ Kafkas University, Department of Science Education, Kars, Turkey \\ Email: solmazaydn@gmail.com
}

\begin{abstract}
This study aims to determine high school students' knowledge and thoughts about microorganisms and to identify the extent to which microorganisms are covered in the high school biology curricula in Turkey. The study sample consisted of 160 secondary students at a science high school in Kars, Turkey. The researcher used the descriptive survey model, applied the Microorganisms Knowledge Test (MKT) to the sample group and did a review of their biology curriculum. It was found that the students are knowledgeable about microorganisms, and that they have generally positive thoughts due to microorganisms' benefits, although microorganisms are not a significant component of their biology lessons.
\end{abstract}

Key words: Microorganisms, high school students, biology curriculum 


\section{Introduction}

These days in which we are experiencing science and technology age, it has been mandatory that students have sufficient knowledge about science and technology, can think critically, can join argumentations, and can take correct decisions. In short, they should be scientifically literate people. Durant (1993) advocates scientific literacy because it, "stands for what the general public ought to know about science." On the other hand, Miller (1983) thinks that it consists of three dimensions: "the nature of science," "science content knowledge," and "the understanding of the effect of science and technology on society and awareness." Scientific literacy has become a keystone of science education and one of the main goals of education programs. Thus, it is important that students are educated in this field.

We frequently encounter the concept of microorganisms both in biotechnology and science, and it is in use in a variety of contexts: TV, newspapers, books, magazines and the like. Today, people are more aware of microorganisms due to increases in biotechnological innovations and consciousness about diseases and hygiene. In this respect, it is important that individuals are knowledgeable and conscious in this field. Studies claim that today students have their own opinions about biological subjects (Simonneaux, 2000; Dawson and Schibeci, 2003; Flores, Tovar, and Gallegos, 2003; Sinatra et al. 2003).

For example, Jones and Rua (2006) conducted a study of microorganisms with fifth, eighth and eleventh grade students and their teachers. They used the term 'germs,' thinking that the fifth grade students might not have been familiar with the concept of microorganisms. The study showed that students regard microorganisms as a human problem, rather that perceiving them as organisms or pathogens in the ecosystem. The researchers also found that students did not have the sufficient information to meet the standards of health education, and that both students and teachers were not well-equipped with knowledge about microorganisms, although microorganisms play a major role in our lives.

Similarly, Simmoneaux (2000) conducted interviews to identify how well students understood the concept of 'microbes' or 'germs.' The students said that viruses were harmful to humans, that bacteria were not too harmful, and that they cause health problems only when they were abundant. The study showed that students thought the main use of bacteria was in the food industry. Students pointed out that they learned about germs, viruses and bacteria 
above all from AIDS awareness campaigns, media and TV cartoons, along with lessons at school and other sources.

Uzunkaya (2007) did a study with sixth grade students, and he used the term 'mikrop' or 'germ,' the concept which the students are the most familiar with, instead of 'microorganism.' He determined that students were mistaken about the concept of germs, what they look like and where they live.

Jones et al. (2013) tried to determine the knowledge and behaviours of university students before and after microbiology courses. They found that there was a positive change in the students' knowledge. Additionally, while some of their behaviours changed such as using a public telephone, touching a faucet in a public bathroom, handling money, borrowing soap from a friend while camping, working in the dirt without gloves, taking out the trash, there were no differences in some of their behaviours such as eating, drinking, kissing, shaking hands or touching a door handle in a public bathroom.

Byrne, Grace, and Hanley (2009) researched the anthropomorphic (anthropomorphism is attribution of human characteristics) and anthropocentric (anthropocentrism refers to a human-centred) opinions of primary and secondary school students regarding microorganisms. They found that students from all age groups had anthropomorphic opinions about microorganisms. Students thought that microorganisms are harmful and dangerous, and they do not know this subject well enough.

These studies in the literature show that students are ill-equipped with knowledge about microorganisms. They only think of bacteria and viruses when they hear the term 'microorganism,' and they have certain misconceptions. Many studies appear to be specific and are focused on the knowledge, attitudes, cognitive structures or perceptions of students about bacteria and viruses, instead of the more general concept of microorganisms (Bliwise et al. 1991; Brook, 1999; Kurt and Ekici, 2013a; Kurt and Ekici, 2013b; Mathews et al. 1990; Maxted, 1984; Simonneaux, 2000). This study aims to help determine the extent of students' learning about microorganisms and examine the place of this subject in their curriculum. Therefore, in this study, I look for the students' levels of knowledge about microorganisms and I examine the biology program in Turkey. Thus, the study aims to make a contribution to the very slight amount of research on microorganisms. 


\section{The Purpose of the Study}

The purpose of this study is to determine high school students' levels of knowledge about microorganisms, their ideas about this subject and to identify the place of microorganisms in the high school biology curriculum. These are the study's main questions:

1. What do the students know about microorganisms?

2. How are microorganisms featured in the high school biology curriculum in Turkey?

\section{Method}

\section{Sampling}

The study sample consisted of 160 secondary students at a science high school in Kars, Turkey. There is only one science high school in Kars. Students in science high schools take more physics, chemistry, and biology courses than students in other high schools. The reason for selecting these students is that science high schools train students who want to study in the field of science at higher education. Investigation of these students' knowledge about microorganisms, will give information about the level of students in science education. The participants were chosen randomly from the volunteers. They were informed about the study, and that they could withdraw at any time. The students' ages ranged between 14 and 18 years. In addition, students have chosen in grades $9-12\left(9^{\text {th }}\right.$ grade $30,10^{\text {th }}$ grade $57,11^{\text {th }}$ grade 42 , $12^{\text {th }}$ grade 31 students)

\section{Materials and Methods}

The researcher used a descriptive survey model, the Microorganisms Knowledge Test (MKT), and did a review of their biology curriculum.

The Microorganisms Knowledge Test (MKT) consists of four open ended questions, and its developer was this study's researcher. The questions were written subsequent to a review of the literature. Three specialists in science education field analysed the form and expressed their thoughts on it, and five high school students read the form to check it for comprehensibility. The researcher used the content analysis method to analyse the results of the Microorganisms Knowledge Test, thus transforming the qualitative data acquired into quantitative data. Then, the content of the responses was analysed in a three phase process. Two researchers read the students' responses independently, and they encoded the questions by editing them as statements that included the students' responses. Another researcher compared the statements generated by these two researchers and examined their consistency. 
Frequencies of the statements that were found reliable at $95 \%$ rate were calculated. The percent of these frequencies were also be calculated and stated within a table.

The document review assessed the curriculum and the course books of the ninth, tenth, eleventh and twelfth grades, and analysed the place of microorganisms in the course content, and the extent to which the students learn about them. Firstly, whether microorganisms were included in the curriculum was determined at each class level. Then, whether microorganisms were included in objectives and activities and the frequency of using the concept of microorganisms in the curriculum were examined. Results of these analyses were given in the result section with details.

\section{Results and Discussion}

\section{Findings for the first sub-problem}

The MKT asks the students four open ended questions: 1) What is a microorganism? 2) Where are microorganisms located? 3) Write down the microorganisms you can name., and 4) What do you know about microorganisms? The researcher classified the students' responses to each question using content analyses and tabulation. Student were allowed give multiple answers or no answer. The researcher calculated the percentages of common responses based the number of students. Table 1 shows the students' responses to the first question:

Table 1. "What is a microorganism?"

\begin{tabular}{lll}
\hline Students' responses & $\mathrm{f}$ & $\%$ \\
\hline They are living cells which are invisible. & 76 & 47.5 \\
\hline They are microscopic creatures. & 33 & 20.6 \\
$\begin{array}{l}\text { They are invisible living cells which are both harmful and } \\
\text { beneficial. }\end{array}$ & 24 & 15 \\
\hline They are invisible, unicellular Protista. & 24 & 15 \\
\hline Protista are microorganisms. & 11 & 6.8 \\
\hline They are small and simply structured living beings. & 9 & 5.6 \\
\hline They are pathogenic living beings. & 2 & 1.2 \\
\hline They are the smallest unit of organism. & 1 & 0.6 \\
\hline
\end{tabular}

Table 1 shows that a many students described microorganisms as, "invisible living cells" (47.5\%), and $20.6 \%$ of them described them as, "microscopic creatures." Of the students, $15 \%$ described them as, "invisible living cells which are both harmful and harmless," and "invisible unicellular Protista." These descriptions show that most of these 
candidate teachers have ideas about microorganisms. In previous studies, students defined microorganisms as invisible, small creatures (Bryne, 2011; Byrne, Grace, and Hanley, 2009; Nagy, 1953; Simonneaux, 2000). In general, students seem to know that microorganisms are microscopic living creatures.

Table 2 shows the students' responses to the question, "Where are microorganisms located?":

Table 2. "Where are microorganisms located?"

\begin{tabular}{lll}
\hline Students' responses & $\mathrm{f}$ & $\%$ \\
\hline They are located everywhere. & 107 & 66.8 \\
\hline They are located on the human body. & 17 & 10.6 \\
\hline They are located in dirty places. & 10 & 6.2 \\
\hline They are located in yoghurt. & 7 & 4.3 \\
\hline They are located in the soil. & 5 & 3.1 \\
\hline They are located in the air. & 5 & 3.1 \\
\hline They are located in mushrooms. & 3 & 1.8 \\
\hline They are located in bread. & 3 & 1.8 \\
\hline They are located on animals and plants. & 2 & 1.2 \\
\hline They are located in water. & 1 & 0.6 \\
\hline
\end{tabular}

When students were asked where microorganisms are located, the majority stated that they are located everywhere $(66.8 \%)$. They also stated that microorganisms are located on the human body (10.6\%), in dirty places (6.2\%), in yoghurt (4.3\%), in the soil $(3.1 \%)$ and in the air $(3.1 \%)$. These figures show that students are informed about the locations of microorganisms. Simonneaux (2000) interviewed students, and they said that bacteria were everywhere, in humid places and in soil. Jones and Rua (2006) interviewed students, teachers and specialists, and the majority of them stated that microorganisms were located everywhere. In addition, they said that microorganisms were frequently located on door handles, tables, books, kitchen--places people usually touch with their hands. Similarly, Faccio et al. (2013) found that most students stated that microorganisms were located everywhere, on the human body and in the air. Bryne et al. (2009) study found that students thought that microorganisms were found on the human body and in dirty places. In his study and the others, students appear to think that microorganisms live almost everywhere, and more specifically in the soil and air, on the human body and in dirty places. Thus, students are accurately informed about the locations of microorganisms. 
Table 3. "Write down the microorganisms you know"

\begin{tabular}{lll}
\hline Students' responses & $\mathrm{f}$ & $\%$ \\
\hline Bacteria & 123 & 76.8 \\
\hline Virus & 94 & 58.7 \\
\hline Archaea & 70 & 43.7 \\
\hline Amoeba & 48 & 30 \\
\hline Paramecium & 48 & 30 \\
\hline Euglena & 44 & 27.5 \\
\hline Fungi & 36 & 22.5 \\
\hline Protista & 31 & 19.3 \\
\hline Algae & 13 & 8.1 \\
\hline Vector & 5 & 3.1 \\
\hline Intestinal bacteria & 4 & 2.5 \\
\hline
\end{tabular}

Table 3 shows that students know which organisms are microorganisms. However, in terms of percentages, first, they think of bacteria (76.8\%), and then, of viruses $(58.7 \%)$. Then they think of archaea (43.7\%), amoeba (30\%), paramecium (30\%), euglena (27.5\%) and fungi $(22.5 \%)$. Some students referred to them as unicellular or protists (19.3\%). Similarly, Jones and Rua (2006) and Uzunkaya (2007) determined in their studies that students think first of bacteria and viruses.

Table 4 shows students' responses to the question, "What do you know about microorganisms?":

Table 4. "What do you know about microorganisms?"

\begin{tabular}{lll}
\hline Students' responses & $\mathrm{f}$ & $\%$ \\
\hline They can be both harmful and harmless. & 110 & 68.7 \\
\hline They are invisible. & 65 & 40.6 \\
\hline They cause diseases. & 55 & 34.3 \\
\hline They are used as yeast. & 44 & 27.5 \\
\hline They are mostly unicellular. & 21 & 13.1 \\
\hline They are located in many places. & 16 & 10 \\
\hline Some of them synthesise vitamins B and K. & 11 & 6.8 \\
\hline They cause rot and mould. & 8 & 5 \\
\hline They cause nitrification. & 5 & 3.1 \\
\hline They have a simple structure. & 5 & 3.1 \\
\hline They reproduce by amitosis. & 3 & 1.8 \\
\hline They digest the cellulose in animal body. & 2 & 1.2 \\
\hline
\end{tabular}




\begin{tabular}{lll}
\hline They are used in the making of antibiotics. & 2 & 1.2 \\
\hline They are prokaryotes. & 2 & 1.2 \\
\hline
\end{tabular}

An evaluation of the students' knowledge about microorganisms shows that most of them say they can be both harmful and harmless (68.7\%).They also think that microorganisms are invisible $(40.6 \%)$, that they cause diseases $(34.3 \%)$, that they are used as yeast $(27.5 \%)$, and that they are unicellular (13.1\%). Table 5 shows that students are well informed about microorganisms. In a review of the literature, Simonneaux (2000) determined that students identified viruses as creatures which are harmful to humans, while they thought that bacteria were not too harmful, only causing health problems when they are abundant. In addition, students said that viruses and bacteria were extremely small, invisible, and used in the food industry.

\section{Findings about the second sub-problem}

The researcher analysed the ninth, tenth, eleventh and twelfth grade biology curricula to identify the extent to which microorganisms feature in them.

\section{Microorganisms in the ninth grade biology curriculum}

In this program, the "classification of living things" is taught, and this subject includes bacteria, archaea, protists and fungi.

Microorganisms are also included in the program's goals and activities. The goals that include microorganisms are (MEB, 2011a):

- The classification of living things: bacteria, archaea, fungi, protists, plants and animals.

- General characteristics of bacteria with examples.

- General characteristics of archaea with examples.

- General characteristics of protists with examples.

- General characteristics of the main sub-groups of plants with examples.

- General characteristics of fungi with examples.

The activities that include microorganisms are Classifying Living Things and Observing Bacteria. The researcher found that the word 'microorganism' is not included in the program. Of course, the tenth, eleventh and twelfth grade students had studied this ninth grade curriculum. In the new program, the subject of 'viruses' is also included.

\section{Microorganisms in the tenth grade biology curriculum}

The program includes these subjects: "respiration in living things: the release of energy," (the fermentation of ethyl alcohol and lactic acid) and "flows of energy in ecosystems and the 
cycling of compounds" (the biogeochemical cycle). The topic of microorganisms is included in these subjects, and in certain goals and activities.

The goals that include microorganisms are (MEB, 2011b):

- An explanation of the creation of ethyl alcohol and lactic acid from glucose in anaerobic respiration.

- Examples of living things that use chemosynthesis.

- An explanation and examples of the role of producers, consumers and decomposers in flows of matter and energy.

The activity that include microorganisms is Anaerobic Respiration in Beer Yeast. The researcher found that the word 'microorganism' is not included in the program.

\section{Microorganisms in the eleventh grade biology curriculum}

The subject of microorganisms is not included in the eleventh grade biology curriculum. The concept of microorganisms is not mentioned in this context (see MEB, 2011c).

\section{Microorganisms in the twelfth grade biology curriculum}

Microorganisms are discussed in the subjects of "digestion" and "circulation and the immune system of the human body." Certain goals and activities also include the concept of microorganism.

The goals that include microorganisms (MEB, 2011d):

- A comparison of tooth and jaw structures, stomach structures and intestinal lengths in herbivorous, carnivorous and omnivorous animals.

- Examples of the body's immunological response to antigens.

- Up-to-date examples of situations in which the immune system reacts to allergens and is put under pressure.

The activities that include microorganisms are Getting to know viruses and Lymph glands and immunity. The concept of microorganisms is used twice: "The role of microorganisms in the digestive systems of mammals," and "When the human body confronts a foreign body or microorganism, how the body prevents its entrance or defends itself when its entrance cannot be prevented."

In the curricula, teaching about microorganisms seems to take place in goals and activities; however, the biotechnological aspect of the concept is not taught adequately. Biotechnology is more important than ever before, and it has a place in the curricula of many countries, such as Australia and New Zealand (Connor, 2000; Dawson, 2001). Students hear and see this concept in various places before twelfth grade, but the concept of microorganisms 
is only explicitly mentioned in the twelfth grade curriculum. This first use of this concept in the curriculum is a little late. Some studies use the term 'germs,' thinking that students might not be familiar with the concept of microorganism, but these studies also determine that students have negative thoughts about 'germs' (Jones and Rua, 2006; Uzunkaya, 2007).

\section{Conclusions}

This research examines high school students' knowledge about microorganisms and the place of microorganisms in the high school biology curriculum. Microorganisms are mentioned in the ninth, tenth and twelfth grade curricula in subjects, goals and in certain activities. However, the subject is discussed under other topics such as 'bacteria' or 'viruses.' Microorganisms, a broader concept, are not discussed. In spite of this situation students appear to know about microorganisms. Students think of bacteria and viruses when they hear the word 'microorganism.' This might be the result of the dominance of bacteria and viruses in the curriculum. In addition, people know about bacteria and viruses since they are the cause of various diseases and widely used in biotechnology. Simonneaux (2000) states that TV programs play a major role in students' awareness of microorganisms. Similarly, Jones and Rua (2006) claim that the media makes a major contribution to all students' knowledge about the concept of microorganisms. For all these reasons, bacteria and viruses appear to be the most widely known microorganisms.

This study found that students have enough information about microorganisms, and the number of students with inaccurate ideas about them is very low. For instance, few students said things like, "Microorganisms are located on mushrooms," (1.8\%) or, "Vectors are microorganisms" (3.1\%). Students were found to know that microorganisms bring both benefits and harm, and in this respect, they have positive ideas about them. Nagy (1953), Jones and Rua (2006), Byrne, Grace, and Hanley (2009), Bryne (2011) and Faccio et al. (2013) found that students think microorganisms mainly cause diseases, and have negative thoughts about them. In this study, a minority of the students have negative thoughts about microorganisms, and the researcher determined that this generally positive attitude is the result of the rise of biotechnological innovations.

Today, microorganisms are in used in the biotechnology industry to produce many of the products we use. Microorganisms have industrial uses in addition to their ability to cause disease. The curriculum should also include teaching about their use in biotechnology along 
with examples of these uses so that students learn scientific information rather than hearsay. However, Dawson and Schibeci (2003) determined that certain factors that limit the teaching of biotechnology: the lack of teachers specialised in the area, the inadequacy of their experience in learning activities, deficiencies in curricula and resources and insufficient teaching durations. The authorities should strive hard to overcome these limiting factors, and focus primarily on teacher training programs.

\section{References}

Bliwise, N. G., Grade, M., Irish, T. M., \& T. J. Ficarrotto. (1991). Measuring medical and nursing students' attitudes toward AIDS. Health Psychology, 10 (4): 289-295.

Brook, U. (1999). AIDS knowledge and attitudes of pupils attending urban high schools in Israel. Patient Education and Counseling, 36 (3): 271-278.

Byrne, J. (2011). Models of Micro-Organisms: Children's knowledge and understanding of microorganisms from 7 to 14 years old. International Journal of Science Education, 33 (14): 19271961.

Byrne, J., Grace, M., \& P. Hanley. (2009). Children's anthropomorphic and anthropocentric ideas about micro-organisms. Journal of Biological Education, 44 (1): 37-43.

Conner, L. (2000). The significance of an approach to the teaching of soci-etal issues related to biotechnology. Paper presented at annual meeting of the American Educational Research Association, New Orleans, LA.

Dawson, V. (2001). Addressing controversial issues in secondary school science. Australian Science Teachers Journal, 47 (4): 38-44.

Dawson, V., \& R. Schibeci. (2003). Western Australian students' understanding of biotechnology. International Journal of Science Education, 25: 57-69.

Durant, J. R. (1993). What is scientific literacy? In J. R. Durant and J. Gregory (Ed.), Science and culture in Europe (pp. 129-137). London: Science Museum.

Faccio, E., Costa, N., Losasso, C., Cappa, V., Mantovani, C., Cibin, V., Andrighetto, I., \& A. Ricci. (2013). What programs work to promote health for children? Exploringbeliefs on microorganisms and on food safety control behavior in primary schools. Food Control, 33: 320-329.

Flores, F., Tovar, M. \& L. Gallegos. (2003). Representation of the cell and its processes in high school students: an integrated view. International Journal of Science Education, 25: 269-286.

Jones, M. G. \& M. J. Rua. (2006). Conceptions of Germs: Expert to Novice Understandings of Microorganisms. Electronic Journal of Science Education, 10 (3): 1-40.

Jones, G., Gardner, G. E.,Lee, T., Poland, K. \& S. Robert. (2013). The Impact of Microbiology Instruction on Students' Perceptions of Risks Related to Microbial Illness. International Journal of Science Education, Part B: Communication and Public Engagement, 3 (3): 199213.

Kurt, H., \& G. Ekici. (2013a). What Is A Virus? Prospective Biology Teachers' Cognitive Structure on the Concept of Virus. International Online Journal of Educational Sciences, 5 (3): 736-756.

Kurt, H., \& G. Ekici. (2013b). Biyoloji öğretmen adaylarının "bakteri” konusundaki bilişsel yapılarının ve alternatif kavramlarının belirlenmesi. Turkish Studies, 8 (8): 885-910.

Mathews, C., Kuhn, L., Metcalf, C., Joubert, G. \& N. Cameron. (1990). Knowledge, attitudes and beliefs about AIDS in township school students in Cape Town. South African Medical Journal, 78: 511-516.

Maxted, M. A. (1984). Pupils' prior beliefs about bacteria and science processes: Their interplay in school science laboratory work. MA thesis, University of British Columbia. 
MEB. (2011a). Ortaöğretim 9. sınıf biyoloji dersi öğretim programı (9th grade biology curriculum). Millî Eğitim Bakanlığı Talim ve Terbiye Kurulu Başkanlığı, Ankara.

MEB. (2011b). Ortaöğretim 10. sınıf biyoloji dersi öğretim programı (10th grade biology curriculum). Millî Eğitim Bakanlığı Talim ve Terbiye Kurulu Başkanlığı, Ankara.

MEB. (2011c). Ortaöğretim 11. sınıf biyoloji dersi öğretim programı (11th grade biology curriculum). Millî Eğitim Bakanlığı Talim ve Terbiye Kurulu Başkanlığı, Ankara

MEB. (2011d). Ortaöğretim 12. sınıf biyoloji dersi öğretim programı. (12th grade biology curriculum). Millî Eğitim Bakanlığı Talim ve Terbiye Kurulu Başkanlığı, Ankara

MEB. (2013). Ortaöğretim biyoloji dersi $(9,10,11$ ve 12. sınıflar) öğretim programı $(9,10,11$ and 12th grade biology curriculum). Millî Eğitim Bakanlığı Talim ve Terbiye Kurulu Başkanlığı, Ankara

Miller, J. D. (1983). Scientific literacy: A conceptual and empirical review. Daedalus 112 (2): 29-48.

Nagy, M. H. (1953). The representation of germs by children. Journal of Genetic Psychology, 83: $227-240$.

Simonneaux, L. (2000). A study of pupils' conceptions and reasoning in connection with 'microbes', as a contribution to research in biotechnology education. International Journal of Science Education, 22 (6): 619-644.

Sinatra, G., Southerland, S., McConaughy, F., \& J. Demastes. (2003). Intentions and beliefs in students' under-standing and acceptance of biological evolution. Journal of Research in Science Teaching, 40: 510-528.

Uzunkaya, A. (2007). Kavram yanılgısı ve çoklu zeka alanlarının ilişkilendirilmesine dayalı bir öğretimin kavram yanılgılarının giderilmesindeki etkisinin incelenmesi: Mikroorganizmalar. MA Thesis, Balıkesir University. 